\title{
Vitamina $\mathrm{C}^{*}$
}

\section{Vitamin $C^{*}$}

Mônica Manela-Azulay'
Absalom Lima Filgueira $^{4}$

\author{
Carlos Alberto Mandarim-de-Lacerda \\ Tullia Cuzzí
}

Maurício de Andrade Perez ${ }^{3}$

\begin{abstract}
Resumo: Há muito o papel do ácido ascórbico (AA) no metabolismo do tecido conjuntivo tem sido reconhecido, sobretudo a partir do século 16, quando o escorbuto começou a ser prevenido com sumo de frutas cítricas.

As primeiras publicações referentes ao uso tópico da vitamina $C$, inicialmente em cobaio, datam da déca da de 1960. Entretanto, só mais recentemente tem-se dado valor a essa via de aplicação. Os autores apre sentam revisão sobre o assunto, discorrendo sobre o histórico da vitamina $\mathrm{C}$, seus efeitos no metabo lismo do tecido conjuntivo, no processo de cicatrização, sobre sua atividade antioxidante e mecanismos de ação.

Palavras-chave: Ácido Ascórbico; Derme; Envelhecimento da Pele

Summary: The role of ascorbic acid in the metabolism of connective tissue bas been recognized since the sixteenth century, when scurvy was prevented by dietary intake of citric fruits.

The earliest reports related to the topical use of vitamin C, initially in Guinea pigs, were published during the sixties. However it was only recently that the value of vitamin $C$ for topical use has been recognized.

The authors present a review of this subject, discussing the effects of vitamin $C$ on the connective tis sue metabolism, wound healing, antioxidant activity and its mechanisms of action.

Key-words: Ascorbic acid; Dermis; Sking Aging
\end{abstract}

\section{INTRODUÇÃO}

A vitamina $\mathrm{C}$ ou, simplesmente, ácido ascórbico (AA) é vitamina hidrossolúvel e termolábil. Os seres humanos e outros primatas, bem como o cobaio, são os únicos mamíferos incapazes de sintetizar o AA. Neles, a deficiência, geneticamente determinada, da gulonolactona oxidase impede a síntese do ácido L-ascórbico a partir da glicose. ${ }^{1,2}$

A dose recomendada para manutenção de nível de saturação da vitamina $\mathrm{C}$ no organismo é de cerca de $100 \mathrm{mg}$ por dia. Em situações diversas, tais como infecções, gravidez e amamentação, e em tabagistas, doses ainda mais elevadas são necessárias., ${ }^{3.4}$ A vitamina C encontra-se na natureza sob duas formas: reduzida ou oxidada (ácido deidroascórbico); ambas são igualmente ati-

\section{INTRODUCTION}

Vitamin C or, simply, ascorbic acid (AA) is soluble in water and thermolabile. Human beings and other primates, as well as guinea pigs, are the only mammals unable to synthesize AA. In these, the genetically determined deficiency in gulonolactone oxidase impedes the synthesis of L-ascorbic acid from glucose. ${ }^{1,2}$

The recommended dose for maintenance of the saturation level of vitamin $C$ in the organism is approximately $100 \mathrm{mg} /$ day. However, in certain situations, such as infections, pregnancy and breastfeeding, as well as among cigarette smokers, even higher doses are necessary. ${ }^{3,4}$ Vitamin $C$ is found naturally in two forms: reduced or oxidized (dehydroascorbic acid); both are equally

Recebido em 14.03.2003. / Received in March, $14^{\text {th }}$ of 2003.

Aprovado pelo Conselho Editorial e aceito para publicação em 06.05.2003. / Approved by the Editorial Council and accepted for publication in May, 06 $6^{\text {th }}$ of 2003.

* Trabalho realizado no Serviço de Dermatologia do HUCFF - UFRJ e no Laboratório de Morfometria \& Morfologia Cardiovascular do Departamento de Anatomia da UERJ como parte da tese de doutoramento. / Work done at the Dermatology service, HUCFF - UFRJ and in the Laboratory of Cardiovascular Morphometry \& Morphology, Dept. of Anatomy, UERJ as part of a doctoral thesis.

${ }^{l}$ Professora Adjunta de Dermatologia - Faculdade de Medicina da UFRJ e Fundação Técnico-Educacional Souza Marques. I Adjunct Professor of Dermatology - School of Medicine, State University of Rio de Janeiro (UERJ) and Fundação Técnico-Educacional Souza Marques.

${ }^{2}$ Professor Titular do Departamento de Anatomia da UERJ. / Titular Professor, Dept. of Anatomy, UERJ.

${ }^{3}$ Professor Assistente do Departamento de Medicina Preventiva - Faculdade de Medicina da UFRJ. / Assistant Professor, Dept. of Preventive Medicine - Medical School, Federal University of Rio de Janeiro (UFRJ).

${ }^{4}$ Professor Titular de Dermatologia - Faculdade de Medicina da UFRJ. / Titular Professor of Dermatology - Medical School, UFRJ.

${ }_{5}^{5}$ Professora Adjunta do Departamento de Patologia - Faculdade de Medicina da UFRJ. / Adjunct Professor, Dept. of Pathology - Medical School, UFRJ. 
vas, porém a forma oxidada está muito menos difundida nas substâncias naturais. A transformação do AA em ácido deidroascórbico ocorre normalmente no interior do organismo e é reversível, permitindo que uma de suas substâncias possa sempre ser transformada na outra. Essa capacidade de transformação funciona como um sistema oxidorredutor capaz de transportar hidrogênio nos processos de respiração, no nível celular. ${ }^{5} \mathrm{O}$ ácido ascórbico participa dos processos celulares de oxirredução, como também é importante na biossíntese das catecolaminas. Previne o escorbuto, é importante na defesa do organismo contra infecções e fundamental na integridade das paredes dos vasos sangüíneos. É essencial para a formação das fibras colágenas existentes em praticamente todos os tecidos do corpo humano (derme, cartilagem e ossos).

\section{HISTÓRICO}

Relatos encontrados em papiros antigos demonstram que desde 1515 A.C. os egípcios tinham conhecimento do escorbuto. Gregos e romanos tiveram suas forças militares dizimadas pela doença. ${ }^{6}$ No final da Idade Média, o escorbuto tornou-se epidêmico no norte e centro da Europa. ${ }^{7}$

Entretanto, foi no século 18, com as grandes e longas viagens marítimas, responsáveis pelo aumento significativo dessa afecção, que a importância da vitamina $\mathrm{C}$ ficou evidente. Os marinheiros que permaneciam a bordo por longos períodos, sem renovar seus suprimentos alimentares, morriam de escorbuto. ${ }^{8}$

Desencadeada pela deficiência de vitamina $\mathrm{C}$ no organismo, essa doença caracteriza-se por manifestações hemorrágicas (petéquias, equimoses, sangramento das gengivas), edema nas articulações, fadiga, lassidão, tonteiras, anorexia, alterações cutâneas, infecções e morte. ${ }^{9}$

James Lind, médico escocês da Marinha Britânica, foi o primeiro a correlacionar a alta morbidade e mortalidade dos marinheiros ingleses com a deficiência da vitamina C. ${ }^{8}$ Em 1747 documentou a ingestão de sucos cítricos no tratamento do escorbuto, realizando o primeiro estudo controlado de que se tem notícia na Medicina. Comparou grupos de tratamento e comprovou que o grupo que recebeu duas laranjas e um limão por dia melhorou drasticamente da doença em uma semana. Os resultados de sua experiência foram publicados em 1753. Em 1795 tornou-se obrigatória, na Marinha Britânica, a ingestão diária de sumos de frutas cítricas.

Em 1911, o bioquímico polonês Casimir Funk utilizou pela primeira vez o termo vitamina para se referir a certas substâncias alimentares imprescindíveis à saúde. Funk foi o descobridor da niacinamida, o fator antiberibéri, e criou a expressão vital amin (amina vital), que deu origem à palavra vitamina. Em 1919 Drummond propôs chamar o fator antiescorbútico de "C". 6

Em 1928, o cientista húngaro Albert von SzentGyorgyi (1893-1986) descobriu e isolou o fator antiescorbuto em vários alimentos, denominando-o vitamina $\mathrm{C} .{ }^{10}$ active, however the oxidized form is much less frequent in natural substances. The transformation of AA into dehydroascorbic acid usually occurs within the organism and is reversible, such that one of the substances can be always transformed into the other. This transformation capacity works as a oxidation-reduction system capable of transferring hydrogen at the cellular level during the breathing processes. ${ }^{5}$ AA not only participates in the cellular processes of oxidation-reduction, but also is important in the biosynthesis of the catecholamines. It prevents scurvy, is an important factor in the organism's defense against infections and is fundamental for the integrity of the walls of the blood vessels. Furthermore, it is essential for the formation of the collagen fibers existent in practically all the tissues of the human body (dermis, cartilage and bones).

\section{HISTORICAL BACKGROUND}

Reports found in ancient papyruses demonstrate that since 1515 BC, the Egyptians had knowledge of scurvy. The military forces of the Greeks and Romans were decimated by the disease. 6 At the end of the Middle Ages, scurvy became epidemic in northern and central Europe.?

However, it was only in the 18th century, when the long sea voyages contributed to a significant increase in this affliction, that the importance of vitamin $C$ became evident. Sailors that remained on-board for long periods without renewing their food supplies succumbed to scurvy. ${ }^{8}$

Triggered by vitamin $C$ deficiency in the organism, this disease is characterized by hemorrhagic manifestations (petechia, ecchymosis and bleeding of the gums), edema in the articulations, fatigue, lassitude, dizziness, anorexia, cutaneous alterations, infections and finally death. ${ }^{9}$

James Lind, a Scottish doctor serving in the British Navy, was the first to correlate the high morbidity and mortality among English sailors with vitamin $C$ deficien$c y .{ }^{8}$ In 1747, the ingestion of citric juices was recorded for the treatment of scurvy, this represented the first controlled study to be documented in the history of Medicine. It compared treatment groups and demonstrated that the group consuming two oranges and a lemon each day presented a major improvement in the clinical picture within one week. The results of his experiment were published in 1753. In 1795 the daily ingestion of citric fruit juices became obligatory in the British Navy.

In 1911, the Polish biochemist Casimir Funk used the term vitamin for the first time to refer to certain alimentary substances indispensable for health. Funk also discovered niacinamide, antiberiberi factor, and created the expression "vital amin", giving origin to the term "vitamin". In 1919, Drummond proposed that "antiscorbutic factor" should be denominated " $C$ ". ${ }^{6}$

In 1928, the Hungarian scientist Albert von SzentGyorgyi (1893-1986) discovered and isolated antiscorbutic factor in several foods, denominating it "vitamin $C^{1 .} .^{10}$ Shortly after, Waugh and King identified the same anti- 
Pouco depois Waugh e King identificaram o mesmo agente antiescorbútico de Szent no sumo do limão. ${ }^{11}$ Hirst e Haworth, em 1933, anunciaram a estrutura da vitamina C e sugeriram, em conjunto com Szent-Gyorgyi, a mudança do nome para ácido ascórbico, por inferência a suas propriedades antiescorbúticas. ${ }^{6}$ No mesmo ano de 1933, Reichstein e colaboradores publicam as sínteses do ácido D-ascórbico e do ácido L-ascórbico, que ainda hoje formam a base da produção industrial da vitamina C. Conseguiram comprovar que o ácido L-ascórbico sintetizado possui a mesma atividade biológica da substância natural. Em 1937, Haworth (Química) e Szent-Gyorgyi (Medicina) são agraciados com o Prêmio Nobel por seus trabalhos com a vitamina $\mathrm{C}^{7}$

Foram, entretanto, as pesquisas do químico americano Linus Pauling (1901-1994), também ganhador do Prêmio Nobel, que popularizaram a vitamina C. Pauling recomendava megadoses da vitamina para o combate de resfriados, gripes e outras viroses, bem como na prevenção do câncer e outras doenças degenerativas. ${ }^{12}$

\section{MECANISMOS DE AÇÃO}

O ácido L-ascórbico é vital para o funcionamento das células, e isso é particularmente evidente no tecido conjuntivo, durante a formação do colágeno. ${ }^{13,14} \mathrm{Na}$ pele, colágenos tipos I e III contribuem com 85 a $90 \%$ e 8 a $11 \%$ do colágeno total sintetizado, respectivamente. ${ }^{15} \mathrm{O}$ AA é co-fator para duas enzimas essenciais na biossíntese do colágeno. A lisil e a prolil hidroxilases catalisam a hidroxilação dos resíduos prolil e lisil nos polipeptídeos colágenos, e essas modificações pós-translacionais permitem a formação e estabilização do colágeno de tripla hélice, e sua subseqüente secreção no espaço extracelular como procolágeno. ${ }^{1} \mathrm{O}$ procolágeno é então transformado em tropocolágeno, e finalmente fibras colágenas são formadas por um rearranjo espacial espontâneo das moléculas tropocolágenas. ${ }^{16}$ Conseqüentemente, a hidroxilação é uma fase crítica na biossíntese de colágeno, uma vez que regula a formação da tripla hélice, da excreção do procolágeno e do cross-linking do tropocolágeno. A lisil e a prolil hidroxilase são enzimas férricas. ${ }^{17} \mathrm{~A}$ vitamina $\mathrm{C}$, como co-fator, previne a oxidação do ferro e, portanto, protege as enzimas contra a auto-inativação. Dessa forma, promove a síntese de uma trama colágena madura e normal por meio da perfeita manutenção da atividade das enzimas lisil e propil hidroxilases. ${ }^{18}$ Além de atuar como importante cofator para as enzimas já citadas, tem sido demonstrado que a vitamina $\mathrm{C}$ regula também a síntese de colágeno tipo I e III, pelos fibroblastos dérmicos humanos. ${ }^{19}$ Trabalho recente demonstrou que, embora a capacidade proliferativa e a síntese de colágeno sejam idade-dependentes, o ácido ascórbico é capaz de estimular a proliferação celular, bem como a síntese de colágeno pelos fibroblastos dérmicos, independente da idade do paciente. ${ }^{18} \mathrm{O}$ AA foi capaz de vencer a capacidade proliferativa reduzida dos fibroblastos dérmicos de indivíduos idosos (78-93 anos), assim como aumentar a síntese de colágeno em níveis similares aos de células de recém-natos (três a oito dias de scorbutic agent as Szent in lemon juice. ${ }^{11}$ Hirst and Haworth, in 1933, announced the structure of vitamin C and suggested, together with Szent-Gyorgyi, that they change the name to "ascorbic acid", in view of its antiscorbutic properties. ${ }^{6}$ In the same year of 1933, Reichstein and collaborators published the synthesis of D-ascorbic acid and L-ascorbic acid, that today still form the basis of the industrial production of vitamin $C$. They managed to demonstrate that synthesized L-ascorbic acid possesses the same biological activity as the natural substance. In 1937, Haworth (Chemist) and Szent-Gyorgyi (Physician) were awarded the Nobel Peace Prize for their work with vitamin $C{ }^{7}$

However, it was the research by the American chemist Linus Pauling (1901-1994), also a winner of the Nobel Peace Prize, that popularized the use of vitamin C. Pauling recommended super doses of the vitamin for the combat of colds, influenza and other viral illnesses, as well as for the prevention of cancer and other degenerative diseases. ${ }^{12}$

\section{ACTION MECHANISMS}

L-ascorbic acid is vital for the operation of the cells and this is particularly evident in the connective tissue, during the formation of collagen. ${ }^{13,14}$ In the skin, collagen types I and III contribute respectively with 85 to $90 \%$ and 8 to $11 \%$ of the total synthesized collagen. ${ }^{15}$ AA is a cofactor for two essential enzymes in the biosynthesis of collagen. The lysil and prolyl hydroxylases catalyze the hydroxylation of the prolyl and lysil residues in the collagenous polypeptides, and these posttranslational modifications enable the formation and stabilization of the triple helix collagen, and its subsequent secretion in the extracellular space as procollagen. ${ }^{I}$ The procollagen is then transformed into tropocollagen and finally collagenous fibers are formed by a spontaneous spatial rearrangement of the tropocollagen molecules. ${ }^{16}$ Consequently, hydroxylation is a critical phase in the biosynthesis of collagen, since it regulates the formation of the triple helix, the excretion of the procollagen and the cross-linking of the tropocollagen. Lysil and prolyl hydroxylases are ferric enzymes. ${ }^{17}$ Vitamin $C$, as a cofactor, prevents oxidation of the iron and, therefore, protects the enzymes against auto-inactivation. In this manner, it promotes the synthesis of a mature and normal collagen pattern through the perfect maintenance of the activity of the lysil and propyl hydroxylase enzymes. ${ }^{18}$ Besides acting as an important cofactor for the enzymes already mentioned, it has been demonstrated that vitamin $C$ also regulates the synthesis of collagen types I and III, for human dermal fibroblasts. ${ }^{19}$ A recent work demonstrated that, although the proliferative capacity and the synthesis of collagen are age-dependent, ascorbic acid is capable of stimulating cellular proliferation, as well as the synthesis of collagen for the dermal fibroblasts, irrespective of the patient's age. ${ }^{18}$ $A A$ was able to overcome the reduced proliferative capacity of the dermal fibroblasts of elderly individuals (78-93 years of 
vida). Esses resultados sugerem que os níveis basais reduzidos da síntese de colágeno em "células velhas" não são devidos a níveis reduzidos de RNA-m dos colágenos I e III, mas sim a eventos reguladores pós-translacionais. Sendo assim, uma vez que oAA é capaz de superar a proliferação diminuída dos fibroblastos dérmicos na pele envelhecida e, ao mesmo tempo, induzir a síntese de colágeno tipos I e III, ele deve se mostrar vantajoso e benéfico no processo de cicatrização. ${ }^{18}$

A matriz extracelular dérmica é responsável pela capacidade elástica e de resistência da pele. Sua alteração, particularmente no curso do envelhecimento, repercutirá na perda das propriedades mecânicas cutâneas e no desenvolvimento das rugas. ${ }^{20}$ As modificações quantitativas desses dois tipos de colágeno (I e III) durante o envelhecimento foram descritas tanto in vitro como in vivo relacionadas à intensidade de irradiação $\mathrm{UV}^{21,2,2,23}$

Foi demonstrado que a produção dos colágenos I e III é estimulada pelo AA, porém mais intensamente no caso do colágeno tipo I. A exposição solar é um acelerador do envelhecimento celular dérmico, sobretudo em sua capacidade de sintetizar os constituintes da matriz celular, mesmo em resposta ao estímulo pelo AA. Os fibroblastos da região pré-auricular (fotoexposta) tiveram sua capacidade de resposta ao AA menor do que a dos fibroblastos da região mamária (não fotoexposta). Ficou demonstrado que, mesmo na camada dérmica, fatores ambientais, como fotoexposição, podem afetar a resposta dos fibroblastos e acelerar o envelhecimento celular. A partir dessas considerações, sugere-se que a diminuição da resposta ao AA possa ser utilizada para quantificar o envelhecimento celular na derme humana, evidenciando a eficácia do tratamento com AA no envelhecimento cutâneo. ${ }^{24}$

O mecanismo pelo qual o AA atua na síntese de colágeno é complexo e ainda não totalmente esclarecido. Recentemente ficou demonstrado que a vitamina $\mathrm{C}$ tópica aumenta o nível de RNA-m dos colágenos I e III, suas enzimas de conversão e o inibidor tissular das metaloproteinases matriciais do tipo 1 , na derme humana. ${ }^{25}$

As proteínas da matriz do tecido conjuntivo são degradadas por várias proteases, principalmente as metaloproteinases, dentre as quais se destacam as colagenases intersticiais, que mediam o passo inicial da degradação do colágeno. ${ }^{26}$

O papel do AA no metabolismo do tecido conjuntivo tem sido reconhecido há muito tempo, mas, sobretudo a partir do século 16, quando o escorbuto começou a ser prevenido com sumo de frutas cítricas, isso ficou mais evidente. Depois, o AA foi tido como co-fator essencial na hidroxilação da prolina e da lisina, aminoácidos necessários para estrutura e função do colágeno. ${ }^{27}$ Estudos conduzidos com cultura de fibroblastos de pele humana demonstraram que o AA estimularia a síntese de colágeno preferencialmente sem afetar a síntese de proteínas não colágenas. Esse efeito não estaria relacionado à propriedade de co-fator, do AA, nas reações de hidroxilação pós-translacionais envolvendo a age) as well as increasing the synthesis of collagen to levels similar to those of cells in newborns (three to eight days of life). These results suggest that the reduced basal levels of the synthesis of collagen in "old cells" are not due to reduced levels of RNA-m of the collagens I and III, but to post-translational regulatory events. This being the case, since AA is able to overcome the reduced proliferation of the dermal fibroblasts in aged skin and, at the same time, induce the synthesis of collagen types I and III, it must also be advantageous and beneficial in the cicatrization process. ${ }^{18}$

The dermal extracellular matrix is responsible for the elasticity and resistance of the skin. Its alteration, particularly during the course of aging, is reflected in the loss of the cutaneous mechanical properties and in the development of wrinkles. ${ }^{20}$ The quantitative modifications of these two types of collagen (I and III) during the aging process have been described both in vitro and in vivo as being related to the intensity of UV irradiation. ${ }^{21,22,23}$

It was demonstrated that the production of collagen I and III is stimulated by AA, however more intensely in the case of collagen type I. Solar exposure is an accelerator of the dermal cellular aging process, above all in terms of its capacity to synthesize the constituents of the cellular matrix, even in response to stimulus from AA. The fibroblasts of the pre-auricular area (photoexposed area) present a lower capacity to respond to AA than the fibroblasts of the mammary region (not solar-exposed). it has been demonstrated that, even in the dermal layer, environmental factors, such as photoexposure, can affect the response of the fibroblasts and accelerate the cellular aging. Based on these considerations, it has been proposed that the decrease in the response to AA could be used to quantify the cellular aging in the human dermis, thereby demonstrating the effectiveness of the treatment for cutaneous aging with $A A{ }^{24}$

The mechanism through which $A A$ acts in the synthesis of collagen is complex and still not fully clarified. Recently it was demonstrated that topical vitamin $C$ increases the level of RNA-m of collagen I and III, their conversion enzymes and the tissular inhibitor of the type 1 matricial metalloproteinases in the human dermis. ${ }^{25}$

The proteins of the connective tissue matrix are degraded by several proteases, mainly the metalloproteinases and especially the interstitial collagenase, which mediate the initial step in the degradation of the collagen. ${ }^{26}$

The role of AA in the metabolism of the connective tissue has been recognized for a long time, but, above all as of the 16 century, when scurvy began to be prevented with the juice of citric fruits. Then, AA was considered an essential cofactor in the hydroxylation of proline and lysine, both amino acids necessary for the structure and function of the collagen. ${ }^{27}$ Studies using cultures of human skin fibroblasts have demonstrated that AA can stimulate the synthesis of collagen specifically without affecting the synthesis of non-collagenous proteins. This effect is not related to the cofactor property of $A A$ in the post-translational hydroxylation reactions involving the synthesis of colla- 
síntese de colágeno, mas sim mediante transcrição genética. A mensuração dessa atividade revelou aumento das cadeias pró-alfa1(I) e pró-alfa 2(I) de quatro vezes e da próalfa1(III) de três vezes, na presença de AA sem aumento na atividade transcritora de genes não colágenos. ${ }^{28}$

O AA estimula a síntese de colágeno especificamente, aumentando os níveis de RNA-m para três diferentes cadeias pró-alfa, codificadas por genes que estão localizados em três cromossomas distintos. ${ }^{29}$ A pró-alfa 1 , no cromossoma $17,^{29}$ a pró-alfa no cromossoma 7 , e a pró-alfa 3 no cromossoma $2 .^{30}$ Possivelmente, o AA atua diretamente, estimulando a transcrição individual dos genes ou, de alguma maneira, a estabilidade do RNA-m individual. ${ }^{29}$

\section{DIAGNÓSTICO}

À medida que a pele envelhece, a derme torna-se fina ${ }^{31}$ e seu conteúdo de colágeno diminui. ${ }^{32}$ Essas alterações são aceleradas pela exposição aos raios UV, de forma crônica. A radiação UV gera a formação de radicais livres. Por sua ação na biossíntese de colágeno e por seu efeito redutor de radicais livres, a possibilidade de liberar doses farmacológicas de ácido L-ascórbico via percutânea apresenta-se como uma interessante e importante terapêutica.

Um estudo realizado em cobaio com escorbuto revelou que, durante a deficiência de ácido ascórbico a pele é o órgão que mais sofre com essa privação, talvez como defesa do organismo, no intuito de poupar órgãos mais nobres. ${ }^{33}$

Os primeiros relatos do uso tópico da vitamina $\mathrm{C}$, a princípio em cobaio, são de cerca de 30 anos atrás. Imai e colaboradores (1967) utilizaram creme de fosfato de ácido ascórbico a 3\% nesses animais e observaram sua absorção através da epiderme até a camada basal. Comparando as duas vias de administração, oral e percutânea, ambas de $1 \mathrm{~g} /$ dia, observou-se melhor resultado em relação ao clareamento da pele com o uso tópico da medicação. Além dessa observação, os autores perceberam que os níveis da vitamina nos locais de aplicação tópica, em comparação com os relativos à vitamina utilizada por via oral, foram mais elevados. ${ }^{34}$

Em relação aos efeitos dos derivados do AA na melanogênese, experimentos com a aplicação tópica de uma pomada contendo fosfato de ácido ascórbico comprovaram que o composto exerce efeito supressor da pigmentação por meio da supressão da ação da tirosinase pelo ácido ascórbico ${ }^{35,36}$ Embora os estudos tenham prosseguido em relação à utilização da vitamina $\mathrm{C}$ tópica, a viabilidade de um produto de uso local, durante muitos anos, foi sempre difícil. O AA é solúvel em água, porém é rapidamente oxidado quando exposto ao ar e não é suficientemente estável para ser aplicado de forma tópica. Por outro lado, sua utilização tópica deve contemplar sua atuação no tecido conjuntivo, devendo, para tanto, penetrar através do extrato córneo e estar disponível para os fibroblastos dérmicos. ${ }^{37}$

Devido à dificuldade de estabilização do $\mathrm{AA}$, vários derivados mais estáveis foram elaborados. Entretanto, gen, but by genetic transcription. Measurement of this activity has revealed a fourfold increase in the pro-alphal(I) and proalpha 2(I) chains and a threefold increase in pro-alphal(III) in the presence of $A A$ without an increase in the transcriptional activity of non-collagenous genes. ${ }^{28}$

AA stimulates the synthesis of collagen specifically, increasing the levels of RNA-m to three different pro-alpha chains, codified by genes which are located in three distinct chromosomes, ${ }^{29}$ namely: pro-alpha 1 , in chromosome $17 ;^{29}$ pro-alpha in chromosome 7; and pro-alpha 3 in chromosome $2{ }^{30}$ It is possible that AA acts directly, stimulating the individual transcription of the genes or, in some manner, the stability of individual RNA-m.29

\section{DIAGNOSIS}

As the skin ages, the dermis becomes thinner, ${ }^{3 l}$ and its collagen content decreases. ${ }^{32}$ These alterations are accelerated by exposure to UV rays, in a chronic way. The $U V$ radiation generates the formation of free radicals. Due to its action in the biosynthesis of collagen and its ability to reduce free radicals, the possibility of applying percutaneous pharmacological doses of L-ascorbic acid presents as an interesting and important therapeutic option.

A study done in guinea pigs with scurvy revealed that, during the ascorbic acid deficiency, the skin is the organ that suffers most from the privation, perhaps as a defense mechanism of the organism, with the purpose of saving more noble organs. ${ }^{33}$

The first reports of the topical use of vitamin $C$, at first in guinea pigs, were published approximately 30 years ago. Imai and collaborators (1967) used 3\% ascorbic acid phosphate cream in these animals and observed its absorption through the epidermis into the basal layer. Comparing the two administration paths (oral and percutaneous) both at $1 \mathrm{~g} /$ day, a better result was observed in relation to the whitening of the skin with the topical use of the medication. Besides this observation, the authors observed that the levels of the vitamin in the places of topical application were higher in comparison with oral use of the vitamin. ${ }^{34}$

In relation to the effects of derivatives of $A A$ in melanogenesis, experiments with the topical application of an ointment containing phosphate of ascorbic acid demonstrated that the compound presents a suppressive effect on the pigmentation through the suppression of the action of tyrosinase by the ascorbic acid. ${ }^{35,36}$ Although the studies have continued in relation to the topical use of vitamin $C$, the viability of a product for local use, was for many years always problematic. AA is soluble in water, however it oxidizes rapidly when exposed to air and is not sufficiently stable to be applied in a topical form. On the other hand, its topical use should consider its role in the connective tissue, for which it must penetrate through the corneum stratum and be available for the dermal fibroblasts. ${ }^{37}$

Due to the difficulty of stabilizing AA, several more stable derivatives have been elaborated. However, although 
embora a estabilidade tenha sido conseguida em muitos deles, o resultado de melhora da pele não era alcançado. Isso se deve ao fato de haver inúmeras variáveis, tais como $\mathrm{pH}$, peso molecular, veículo, percentagem do derivado ascórbico viável na derme, para citar apenas algumas, o que dificulta o desenvolvimento de um produto para aplicação tópica de $\mathrm{AA} \cdot{ }^{38}$ Não há derivados do AA que demonstrem atividade maior do que o próprio, e os ésteres possuem atividade de vitamina $\mathrm{C}$ tanto menor quanto maior for o número de radicais substituídos. ${ }^{35,39} \mathrm{O}$ ascorbil 6-palmitato, por exemplo, embora penetre a pele, é ineficiente em sua conversão para o ácido L-ascórbico, a forma ativa da vitamina C. ${ }^{40}$ Por sua vez, o ascorbil fosfato de magnésio não é capaz de atravessar o estrato córneo. ${ }^{41}$ Embora sejam derivados efetivos da vitamina $\mathrm{C}$ para uso oral, não substituem o ácido L-ascórbico nas formulações tópicas.

Estudos da absorção percutânea do ácido L-ascórbico tópico em porcos revelaram a importância do $\mathrm{pH}$ na formulação tópica do ácido. Os níveis teciduais do AA só aumentaram com a utilização de formulações com níveis de $\mathrm{pH}$ iguais a 3,5 ou menores do que isso.

Vitamina C em percentagens de 5 a $30 \%$ também foi testada, e os níveis teciduais foram aumentando proporcionalmente à concentração da vitamina. A concentração de $20 \%$ foi a responsável pelo nível máximo de vitamina no tecido. Por razões desconhecidas, concentrações acima desse valor resultaram em diminuição dos níveis teciduais do AA. ${ }^{38}$

Outro achado interessante refere-se ao grau de saturação da vitamina na pele. A aplicação diária de ácido L-ascórbico a $15 \%$ formulado em pH 3.2, após três dias, atingiu nível 20 vezes maior de saturação no tecido do que o controle. Após a saturação do reservatório da pele, o ácido L-ascórbico manteve-se estável e presente no tecido com meia-vida de aproximadamente quatro dias. ${ }^{38}$ Como antioxidantes tópicos já demonstraram exercer função de fotoproteção $0^{42}$ e o próprio ácido L-ascórbico é capaz de diminuir o eritema desencadeado pela irradiação UVB, ${ }^{42,43}$ um reservatório persistente de antioxidantes seria uma estratégia interessante e atrativa de fotoproteção em comparação com os filtros solares que necessitam ser aplicados diariamente. ${ }^{44}$

Os radicais livres gerados a partir da irradiação solar, do fumo, poluição, etc. causam oxidação dos ácidos nucléicos, proteínas e lipídios, alterando o DNA, bem como sua reparação, disparando a cascata das citoquinas e resultando em fotoenvelhecimento ${ }^{45}$ e fotocarcinogênese. ${ }^{46}$

$\mathrm{O}$ organismo humano protege-se naturalmente utilizando antioxidantes para neutralizar os efeitos nocivos dos radicais livres. A vitamina $\mathrm{C}$ é o antioxidante mais abundante no organismo, especialmente na pele. É conhecida a importância do ácido L-ascórbico tópico como eficiente neutralizador dos radicais livres. ${ }^{47}$ stability has been acheived in many of these, a resulting improvement of the skin has not been observed. This is due to the fact that there are countless variables, such as $\mathrm{pH}$, molecular weight, vehicle, and percentage of ascorbic derivative viable in the dermis, to mention only several, which hinders the development of a product for topical application of $A A{ }^{38}$ There are no derivatives of $A A$ that demonstrate a greater activity than AA itself, and the esters possess an activity of vitamin $C$ which decreases as the radicals are substituted. ${ }^{35,39}$ Ascorbyl 6-palmitate, for instance, although it penetrates the skin, is inefficient in terms of its conversion into $L$-ascorbic acid, which is the active form of vitamin $C^{40}$ While magnesium ascorbyl phosphate is not able to cross the corneum stratum..$^{4 l}$ Although these are effective derivatives of vitamin C for oral use, they are no substitute for $L$-ascorbic acid in topical formulations.

Studies of the percutaneous absorption of topical Lascorbic acid in pigs have revealed the importance of $\mathrm{pH}$ in the topical formulations of the acid. The tissular levels of AA only increased with the use of formulations with $\mathrm{pH}$ levels less than or equal to 3.5.

Vitamin C in percentages from 5 to $30 \%$ were also tested, and the tissular levels increased proportionally to the concentration of the vitamin. A concentration of $20 \%$ was found to provide the maximum level of vitamin in the tissue. For unknown reasons, concentrations over this value resulted in a decrease in the tissular levels of $A A .^{38}$

Another interesting finding refers to the degree of saturation of the vitamin in the skin. The daily application of $15 \%$ L-ascorbic acid formulated with $\mathrm{pH} 3.2$, after three days, reached a 20 times higher saturation level in the tissue compared to the control group. After saturation of the cutaneous reservoir, L-ascorbic acid remained stable and present in the tissue with a half-life of approximately four days. ${ }^{38}$ As it has already been demonstrated that topical antioxidants exercise a function of photoprotection ${ }^{42}$ and $L$ ascorbic acid is capable of reducing the erythema provoked by UVB irradiation, ${ }^{42,43}$ a persistent reservoir of antioxidants would be an interesting and attractive strategy for daily solar protection in comparison with the topical sunscreens that need to be applied each day. ${ }^{44}$

The free radicals generated by the solar irradiation, tobacco, pollution, etc. cause oxidation of the nucleic acids, proteins and lipids, both altering and repairing the DNA, as well as triggering a cascade of cytokines and resulting in photoaging ${ }^{45}$ and photocarcinogenesis. ${ }^{46}$

The human organism protects itself naturally by using antioxidants to neutralize the noxious effects of the free radicals. Vitamin $C$ is the most abundant antioxidant in the organism and especially in the skin. Topical L-ascorbic acid is known as an important and efficient neutralizer of free radicals. ${ }^{47}$

\section{CONCLUSÕES}


Em adição a seus efeitos antioxidantes, o AA é importante na cicatrização das feridas, essencial na síntese de colágeno, atuando como co-fator para as enzimas lisil e propil hidroxilases, e estimulando a transcrição dos genes do colágeno. Tem sido utilizado também como clareador cutâneo, inibindo a tirosinase. ${ }^{48}$ Provê suplemento seguro e efetivo de armazenamento nos tecidos, melhorando a fotoproteção e aumentando as defesas antioxidantes.

Com tantas qualidades e benefícios, sem dúvida alguma, a vitamina $\mathrm{C}$ merece continuar a ser investigada em todas as suas implicações, sobretudo em sua forma tópica, no nível cutâneo, criando linhas de pesquisa nas áreas de fotoenvelhecimento e fotocarcinogênese.

\section{REFERÊNCIAS / REFERENCES}

1. Pinnel SR, Murad S, and Darr D, Induction of collagen synthesis by ascorbic acid. A possible mechanism. Arch Dermatol, 1987;23(12):1684-6.

2. Nishikimi MR, Fukuyama S, Minoshima N, Shimizu and K, Yagi. Cloning and chromosomal mapping of the human nonfunctional gene for L-gulono-gamma-lactone oxidase, the enzyme for L-ascorbic acid biosynthesis missing in man. J Biol Chem, 1994; 269(18):13685-8.

3. Hornig D, Metabolism and requirements of ascorbic acid in man. S Afr Med J, 1981;60(21)818-23.

4. Schectman G, Estimating ascorbic acid requirements for cigarette smokers. Ann N Y Acad Sci, 1993;686:335-45;discussion 345-6.

5. Welch RW, Wang YA, Crossman JB Jr, Park KL, Kirk and M, Levine. Accumulation of vitamin $\mathrm{C}$ (ascorbate) and its oxidized metabolite dehydroascorbic acid occurs by separate mechanisms. J Biol Chem, 1995;270(21):12584-92.

6. Sharman IM, Vitamin C: Historical aspects, in Vitamin C, Recent Aspects of its Physiological and Technological Importance, GG Birch and KJ Parker, Editors. 1974; Halsted Press Book, Wiley:New York.1-15.

7. Carpenter KJ. The history of scurvy and vitamin C. 1986; Cambridge: Cambridge University Press. 423.

8. Lind JA treatise on the scurvy, ed. C.P. Stewart and D. Guthrie. 1953;Edinburgh: Edinburgh University Press.

9. Crandon JC, Lund and Dill D. Experimental human scurvy. N Engl J Med, 1940. 223:353-69.

10. Szent-Gyorgy A, Vitamin C. J Biol Chem.1928;22:1387-1409. 11. Waugh WA, and CG King, Isolation and identification of vitamin C. J Biol Chem, 1932;97:325-31.

12. Pauling L, Evolution and the need for ascorbic acid. Proc Natl Acad Sci USA, 1970;67(4):1643-8.

13. Fenske NA, and CW Lober, Structural and functional changes of normal aging skin. J Am Acad Dermatol, 1986;15(4 Pt1):57185.

14. Yaar M, and Gilchrest BA, Cellular and molecular mechanisms of cutaneous aging. J Dermatol Surg Oncol, 1990;16(10): 915-22.

15. Smith LT, Holbrook KA, and Madri JA, Collagen types I, III,
In addition to its antioxidant effects, AA is important in wound cicatrization, essential for the synthesis of collagen, acting as a cofactor for the lysil enzymes and propyl hydroxylases, and stimulating the transcription of the collagen genes. It has also been used as a skin whitener, by inhibiting tyrosinase. ${ }^{48}$ It provides a safe and effective supplement for the reservoir in tissues, improving the levels of photoprotection and increasing the antioxidant defenses.

With so many qualities and benefits, vitamin $C$ undoubtedly merits further investigation into in all its implications, above all in topical form at cutaneous level, creating lines of research in the areas.

and $\mathrm{V}$ in human embryonic and fetal skin. Am J Anat, 1986; 175(4):507-21.

16. Chan D, Lamande SR, Cole WG, and Bateman JF. Regulation of procollagen synthesis and processing during ascorbate-induced extracellular matrix accumulation in vitro. J Biol Chem, 1990; 269(1):175-81.

17. Boyera N, Galey I, and Bernard BA. Effect of vitamin C and its derivatives on collagen synthesis and cross-linking by normal human fibroblasts. International Journal of Cosmetic Science, 1998;20:151-8.

18. Phillips CL, Combs SB, and Pinnell SR. Effects of ascorbic acid on proliferation and collagen synthesis in relation to the donor age of human dermal fibroblasts. J Invest Dermatol, 1994; 103(2):228-32.

19. Welch RW, Bergsten P, Butler JD, and Levine M. Ascorbic acid accumulation and transport in human fibroblasts. J Biol Chem, 1993;294(Pt 2):505-10.

20. Lapiere CM. The ageing dermis: the main cause for the appearance of 'old' skin. Br J Dermatol, 1990;122(Suppl 35):5-11. 21. Kligman LH. Photoaging. Manifestations, prevention, and treatment. Clin Geriatr Med, 1989;5(1):235-51.

22. Oikarinen A, and Kallioinen M. A biochemical and immunohistochemical study of collagen in sun-exposed and protected skin. Photodermatol, 1989;6(1):24-31.

23. Talwar HS, Griffiths CE, Fisher GJ, Hamilton TA, and Voorhees JJ. Reduced type I and type III procollagens in photodamaged adult human skin. J Invest Dermatol, 1995;105(2):285-90.

24. Dumas MC, Chaudagne F, Bonte and Meybeck A. Age-related response of human dermal fibroblasts to L-ascorbic acid: study of type I and III collagen synthesis. CR Acad Sci III, 1996;319(12): 1127-32.

25. Nusgens BV, Humbert P, Rougier A. et al. Topically applied vitamin $\mathrm{C}$ enhances the mRNA level of collagens I and III, their processing enzymes and tissue inhibitor of matrix metalloproteinase 1 in the human dermis. J Invest Dermatol, 2001;116(6): 853-9.

26. Nagase H, and Woessner JF Jr. Matrix metalloproteinases. J Biol Chem, 1999;274(31):21491-4.

27. Englard S, and Seifter S. The biochemical functions of ascor- 
bic acid. Annu Rev Nutr, 1986;6:365-406.

28. Tajima S, and Pinnell SR. Ascorbic acid preferentially enhances type I and III collagen gene transcription in human skin fibroblasts. J Dermatol Sci, 1996;11(3):250-3.

29. Junien C, Weil D, Myers JC. et al. Assignment of the human pro alpha 2(I) collagen structural gene (COLIA2) to chromosome 7 by molecular hybridization. Am J Hum Genet, 1982;34(3):381-7.

30. Emanuel BS, Cannizzaro LA, Seyer JM, and Myers JC. Human alpha 1(III) and alpha 2(V) procollagen genes are located on the long arm of chromosome 2. Proc Natl Acad Sci USA, 1985;82(10):3385-9.

31. Tan CY, Statham B, Marks R, and Payne PA. Skin thickness measurement by pulsed ultrasound: its reproducibility, validation and variability. Br J Dermatol, 1982;106(6):657-67.

32. Shuster S, Black MM, and McVitie E. The influence of age and sex on skin thickness, skin collagen and density. $\mathrm{Br} \mathrm{J}$ Dermatol, 1975;93(6):639-43.

33. Bates CJ. Vitamin C deficiency in guinea pigs: variable sensitivity of collagen at different sites. Int J Vitam Nutr Res, 1979; 49(1):77-86.

34. Imai Y, Usui T, Matsuzaki T, Yokotani H, and Mima H. The antiscorbutic activity of L-ascorbic acid phosphate given orally and percutaneously in guinea pigs. Jpn J Pharmacol, 1967;17(2): 317-24.

35. Takashima H, Nomura H, Imai Y, and Mima H. Ascorbic acid esters and skin pigmentation. American Perfumer and Cosmetics, 1971.86:7.

36. Maeda K. and Fukuda M. Arbutin: mechanism of its depigmenting action in human melanocyte culture. J Pharmacol Exp Ther, 1996;276(2):765-9.

37. Garcia-Mercier C, Richard A, and Rougier A. Effect of a water/oil emulsion containing ascorbic acid on collagen neosynthesis in human full thickness skin discs in culture. EJD, 2002; 12(4):XXX-XXXI.

38. Pinnell SR, Yang H, Omar M, et al. Topical L-ascorbic acid: percutaneous absorption studies. Dermatol Surg, 2001;27(2):137-42.

39. Traikovich SS. Use of topical ascorbic acid and its effects on photodamaged skin topography. Arch Otolaryngol Head Neck
Surg, 1999;125(10):1091-8.

40. Ross D, Mendiratta S, Qu ZC, Cobb CE, and May JM. Ascorbate 6-palmitate protects human erythrocytes from oxidative damage. Free Radic Biol Med, 1999;26(1-2):81-9.

41. Kameyama K, Sakai C, Kondoh S, et al. Inhibitory effect of magnesium L-ascorbyl-2-phosphate (VC-PMG) on melanogenesis in vitro and in vivo. J Am Acad Dermatol, 1996;34(1):29-33. 42. Darr D, Combs S, Dunston S, Manning T, and Pinnell S. Topical vitamin $\mathrm{C}$ protects porcine skin from ultraviolet radiationinduced damage. Br J Dermatol, 1992;127(3):247-53.

43. Nakamura T, Pinnell SR, Darr D, et al. Vitamin C abrogates the deleterious effects of UVB radiation on cutaneous immunity by a mechanism that does not depend on TNF-alpha. J Invest Dermatol, 1997;109(1):20-4.

44. Steenvoorden DP, and GM. Beijersbergen van Henegouwen, Cysteine derivatives protect against UV-induced reactive intermediates in human keratinocytes: the role of glutathione synthesis. Photochem Photobiol, 1997;66(5):665-71.

45. Fisher GJ, Wang ZQ, Datta SC, Varani J, Kang S, and Voorhees JJ. Pathophysiology of premature skin aging induced by ultraviolet light. N Engl J Med, 1997;337(20):1419-28.

46. Runger TM. Role of UVA in the pathogenesis of melanoma and non-melanoma skin cancer. A short review. Photodermatol Photoimmunol Photomed, 1999;15(6):212-6.

47. Pinnell SR. Cutaneous photodamage, oxidative stress, and topical antioxidant protection. J Am Acad Dermatol, 2003;48(1):1-19; quiz 20-2.

48. Humbert $P$. Topical vitamin $C$ in the treatment of photoaged skin. Eur J Dermatol, 2001;11(2):172-3.

ENDEREÇO PARA CORRESPONDÊNCIA: / MAILING ADDRESS:

Mônica Manela Azulay

Av. das Américas, 2111 salas 102, 103 e 104

Barra da Tijuca Rio de Janeiro RJ 22631-000

Tel.: (21) 2493-8418

E-mail:m.azulay@msm.com.br 
1) Uma das principais ações relacionadas à Vitamina $C$ refere-se a formação de colágeno, sendo essencial na biossíntese de enzimas fundamentais nessa formação. Assinale uma das enzimas envolvidas neste processo.
a) Lisil sintetase
b) Metaloproteinase III
c) Kinerase
d) Prolil hidroxilase

2) Uma das ações benéficas da Vit $C$ estaria relacionada ao clareamento da pele, determinado principalmente devido:
a) Estimulação indireta da tirosinase
b) Inibição específica dos melanossomas
c) Inibição da tirosinase
d) Ação deletéria aos melanócitos

3) Vários derivados da Vitamina $\mathrm{C}$ já foram testados $\mathrm{e}$ utilizados, mas com absorção errática. Qual apresenta maior eficácia?
a) Ascorbil 6-palmitato
b) Ascorbil fosfato de magnésio
c) Ácido L-ascórbico
d) Alendronato de vitamina $\mathrm{C}$

4) A absorção da vitamina $\mathrm{C}$ é diretamente proporcional à concentração empregada até um limite determinado de:
a) $20 \%$
b) $5 \%$
c) $10 \%$
d) $25 \%$

5)Um pai levou ao consultório o filho de 4 anos de idade, com fototipo 1. Queixava-se que todas as vezes que o filho brincava na praia, retornava com vermelhão intenso. Além do fotoprotetor, o dermatologista prescreveu vitamina C. Qual o provável motivo da associação com a vitamina C?

a) Diminuir o eritema pelo UV B

b) Aumentar por via indireta a oxidação dos ácidos nucléicos

c) Restauração do limiar cutâneo à

fotoexposição

d) A associação é completamente indevida podendo agravar o eritema pela fotossensibilidade da medicação

6) $\mathrm{Na}$ alimentação onde podemos encontrar quantidades mais elevadas de vitamina $\mathrm{C}$
a) Espinafre
b) Frutas cítricas
c) Carne de frango
d) Queijo

7) Qual o órgão mais afetado na redução grave de vitamina $\mathrm{C}$
a) Baço
b) Intestino grosso
c) Pulmão
d) Pele

8) Além das manifestações dermatológicas outras manifestações clínicas comumente na deficiência de vitamina exceto:
a) Fadiga
b) Tonteira
c) Anorexia
d) Acatisia

9) Os seres humanos e os cobaios são os únicos mamíferos incapazes de sintetizar o ácido ascórbico. Este fato está relacionado a deficiência da enzima:
a) Uridil-tranferase III
b) Co-sintetase $\mathrm{C}$
c) Gulonolactona oxidase
d) Dopa oxidase

10) Quais os tipos de colágeno mais relacionados à vitamina $\mathrm{C}$ ?
a) I e IV
b) II e IV
c) I e III
d) II e III

11) $\mathrm{O} p H$ ideal para formulação da vitamina $\mathrm{C}$ tópica deverá ser de:
a) Menor que 3.5
b) Entre 3.5 e 4.5
c) Entre 4.5 e 6
d) Não há diferenças quanto a absorção determinadas pelo $\mathrm{pH}$ da medicação

12) Como características físico-químicas importantes na formulação do ácido ascórbico, podemos salientar:
a) hidrossolubilidade e termoestabilidade
b) lipossolubilidade e termolabilidade
c) absorção cutânea aumentada em pH ácido
d) absorção cutânea reduzida em pH ácido

13) A dose recomendada para manutenção do nível de saturação da vitamina $\mathrm{C}$ no organismo é de:
a) $500 \mathrm{mg} / \mathrm{d}$
b) $1 \mathrm{~g} / \mathrm{d}$
c) $250 \mathrm{mg} / \mathrm{d}$
d) $100 \mathrm{mg} / \mathrm{d}$ 
14) Em pacientes com desnutrição grave e carência de vitamina $\mathrm{C}$, podemos observar as seguintes manifestações dermatológicas:
a) frinoderma
b) eflúvio telógeno
c) equimoses
d) perlèche

15) Na síntese de colágeno, a vitamina $C$ desempenha importante papel, aumentando os níveis de RNA-m. Os genes responsáveis por esta codificação estão localizados nos cromossomos:
a) 3,7 e 19
b) 2,7 e 17
c) 2,9 e 18
d) 3,7 e 18

\section{AGRADECIMENTO}

Ao Dr. Arles Brotas, mestrando do curso de Pós-graduação em dermatologia, pela colaboração na confecção das questões.

\section{GABARITO}

Paracoccidioidomicose: atualização epidemiológica, clínica e terapêutica

2003; 78(2): 135-150

$\begin{array}{ll}01-\mathrm{a} & 09-\mathrm{d} \\ 02-\mathrm{b} & 10-\mathrm{a} \\ 03-\mathrm{b} & 11-\mathrm{d} \\ 04-\mathrm{d} & 12-\mathrm{d} \\ 05-\mathrm{d} & 13-\mathrm{d} \\ 06-\mathrm{d} & 14-\mathrm{d} \\ 07-\mathrm{d} & 15-\text { ANULADA } \\ 08-\mathrm{d} & \end{array}$

\section{NOTA}

A questão ${ }^{\circ} 15$ da EMC-D referente ao trabalho "Paracoccidioidomicose: atualização epidemiológica, clínica e terapêutica" foi anulada por possuir duas alternativas corretas. Todos os sócios que responderam ao questionário serão pontuados nesta questão. 